\title{
Impact of Customers Relationship Marketing On Customers Satisfaction in Dashn Bank at Wolaita Sodo Town
}

\author{
Biruktait Girma Giday*, Million Nane Elcho (PhD) ${ }^{* *}$ \\ *Department of Management, Wolaita Sodo University \\ *** Department of Management, Wolaita Sodo University \\ DOI: 10.29322/IJSRP.11.07.2021.p11561 \\ http://dx.doi.org/10.29322/IJSRP.11.07.2021.p11561
}

\begin{abstract}
The study is aimed to investigate the impact of customer relationship marketing on customer satisfaction of Dashen Bank at Wolaita Sodo Town and measured customer relationship market tactics and its impact on customer satisfaction. Survey method was used as the research method of the study. The sample for the study consists of 394 respondents selected based on convenience sampling procedure. The dimensions of the study were service quality, price perception, brand image and value offered. Study data were collected using self-administered questionnaire and the questionnaire consisted of 18 items categorized under four dimensions of the Likert scale model. Correlation and multiple regressions were used to investigate the relationship between dependent and independent variables. The correlation results indicate that there was a positive and significant association between all dimensions of customer relationship market tactics with customer satisfaction. The results of the regression test showed that all customer relationship market tactics except brand image have positive and significant impact on overall customer satisfaction. The research proves that service quality and price perception plays the most important role in customer satisfaction level followed by value offered. However, the regression results showed that there was insignificant relationship between brand image and customers satisfaction. Accordingly, study recommends that ensuring high customer relation tactics increases customer satisfaction.
\end{abstract}

Index Terms- Brand Image, Customer Satisfaction, Service Quality, Price Perception, Value Offered

\section{INTRODUCTION}

$\mathrm{C}$ ustomer Relationship Marketing Management practices in banking service is the establishment, development, maintenance and optimization of long term mutually valuable relationships between consumers and the organizations. Studies of the impact of relationship marketing on customer satisfaction outcomes lean to approach the way customers encounter a problem with regard to the market relationship provided by the banks. A small group of studies treat that customer satisfaction is a function of service quality, price perception, brand image, and value offered. The evidence is almost uniformly consistent in indicating the effects of MRM tactics in customers' satisfaction (Lacey and Morgan, 2009).

The survival of any organizations depends on its customers' satisfaction. Customers are the source of profits to be earned by a profit making organization and the primary reason for being in the operation for not profit making organizations. Thus, customers are the backbone and lifeline of organizations. Often it is said that without customers, there is no business. They are an asset for business organization.

Worthington \& Horne (1998) conducted research on a new relationship marketing model and its application and concluded that relationship marketing is being put forward as a new paradigm for marketing and is particularly relevant for the marketing of financial services, with their potential for long term and wide relationships between financial institutions and customer.

Ferguson \& Havinka (2007) revealed that banks are customizing their relationship building strategies to create value propositions as unique as the institutions and customers they serve. They also indicated that when banks use loyalty programs to bring about trust and build confidence in the brand, the customer relationship will develop organically, and so will profits. It is argued that building enduring customer relationships is the secret to furthering growth and should be an unquestioned axiom by bankers.

Relationship marketing gives a company new opportunities to gain a competitive edge by moving customers up a loyalty hierarchy from new customers to regular purchasers, then to loyal supporters of the firms goods and services, and finally to advocates who not only buy its products but recommend them to others (Smith, 2003). By converting indifferent customers into loyal ones, companies generate repeat sales. The cost of maintaining existing customers is far below the cost of finding new ones, and these customers satisfaction are profitable ones.

The implementation of customer relation management as a tool of competitive strategy is on the rise in different financial institutions across the world. Yet there is no doubt that an effective and efficient practice of customer management is important to the successes of financial institutions such as banks. According to Parvatiyar and Sheth (2002), most of the firms implementing customer management strategies are highly benefit of it, because there are no laid down guidelines and procedures on adoption, implementation and strategies. 
Lacey and Morgan (2009) findings suggest that customers with stronger levels of commitment are indeed more willing to contribute as customer advocates. They also pointed out that relationship marketing represents a dramatic change in buyer seller interactions from the previous transaction based marketing that focused on a single transaction. Effective relationship marketing heavily relies on developing strategic partnerships with customers (Boone \&Kurtz, 2005).

Ethiopian banks are introducing innovative banking technologies to satisfy customer interests. However, problems remain in areas of customer handling (Solomon Amare, 2014). Many researchers have found empirical evidence to support the relationship between market relationship management tactics and customer satisfaction (Athanassopoulos et al., 2001; Caruana, 2002). Developing a profitable and long term relationship with customers is one of the objectives of public and private commercial banks. Therefore, the author of this research focused on understanding the major market relationship management tactics that will influence customer's satisfaction.

Therefore, the main objective of the study is to assess the impact of customer market Relationship Management Tactics on customer's satisfaction in Dashen Bank in Wolaita Sodo Town, Southern Nations, Nationalities and People Regional State, Ethiopia.

\section{Statement of the Problem}

Confronted with the fierce competition in today bank marketplace, there have been many marketing strategies for service providers to plan and implement. However, consumers are disturbed by a number of marketing activities ranging from aggressive sales tactics, telemarketing, direct mail, doorstep selling, radio advertisement, television advertisement, and internet promotion to customer satisfaction programmers (Peng and Wang, 2006). There are also evidences that show consumers tend switch over to the other competitors when they cannot be satisfied with the customer's relationship marketing tactics offered by the firm in question.

Customer relationship marketing strategy might be one of the best ways for service providers to ensure customers satisfaction and building customer loyalty. Many empirical studies have provided evidences that customer's relationship marketing tactics have impact on behavioral customer's satisfaction which affects customer retention. Therefore, well awareness of the target consumers and building good relationship with them is the most significant issue.

The challenge for financial institutions service providers is to attract more customers, focus on building good relationship quality with customers, make customers satisfied and trust, and step by step obtain customer's satisfaction, through customers' relationship marketing strategies.

As the competitive environment becomes more turbulent, the most important issue the sellers face is no longer to provide excellent, good quality products or services, but also to keep satisfied customers who will contribute long term profit to organizations.

In the banking industry, offering quality services is very important to create closer relationship with the entire customers. Quality of services has the power to create customer satisfaction. On the other hand poor quality of services results in customer dissatisfaction and customer defection by going to other competitors.

Sustainable and continuous survival of an organization mainly depends on its business relation with its customers. When business firms direct their resources and all their efforts for better accomplishment of their intended purposes, growth and profitability is entirely influenced by the quality and reliability of their service. These could be done through delivering a service that could increase the acceptance of the organization in the face of the customers.

Organizations need some mechanisms that could increase customer satisfaction in a coordinated and change oriented bases. One of the mechanisms that can give such benefit is Customer Relationship Marketing Tactics. It is the process that organizations has to understand the customers like or/and dislike and serve the customers according to their desire to anchor them for continuous customers satisfaction and there by ensure relationship (Kotler \& Armstrong, 2010). It is done by gathering the related information of customers in an organized manner, analyzing and interpreting it so that it can help the organization to fulfill the need of its customers.

The application of customer relationship marketing tactics is crucial in these days. Because a fierce competition all over the world and the effect of globalization, being reluctant to accept will customer relationship marketing tactics cost the organization a big deal of lose in many directions; losing a potential customers and market share, letting down the reputation of the organization, lagging behind industry leaders, shortage of information from customers that could give big advantage, failure of employees to understand customers nicely and many more will be the negative impact.

Today, Ethiopian banks are facing challenges with stiff competition. Hence, creating effective customers relationship marketing management and customer satisfaction is expected of them to win this competition. So, it becomes very important for banks to meet or exceed the target customers' satisfaction with customer market relationship management. Therefore the general objective of this study is to investigate the effect of customer relationship marketing tactics or dimensions (service quality, fair price, brand image, and value offered) on customer satisfaction in Dashen Bank.

\section{Research Hypothesis}

Ho1: Perceived service quality has no effect on customer satisfaction.

H02: Perceived fair price has no effect on customer satisfaction.

H03: Perceived positive brand image has no effect on customer satisfaction.

H04: Perceived value offered has no effect on customer satisfaction.

\section{BRIEF LITERATURE REVIEW}

\section{An Overview of Relationship Marketing}

During the last decade of the $20^{\text {th }}$ century, relationship marketing has been seen as the mainstream of though in planning a marketing strategy both in industrial marketing and consumer marketing (Tseng, 2007). According to Morgan and Hunt (1994), 
relationship marketing was defined as all the marketing activities that are designed to establishing, developing, and maintaining successful relationship marketing with customers.

Hougaard and Bjerre (2002) also defined relationship marketing as company behavior with the purpose of establishing, maintaining and developing competitive and profitable customer relationship to the benefit of both parties. Due to the profitable relationship on a lifetime basis may also create loss in some stages during the lifetime.

Wulf et al. (2001) suggested that different levels of relationship duration would result in different levels of consumption experience, producing different results, satisfaction and loyalty with different relationship marketing tactics. Compared with traditional marketing, relationship marketing is more concerned about building customer relationships in order to achieve long term mutual benefits for all parties involved in the exchanges. Relationship marketing essentially means developing customers as partners, where an approach is different from traditional transaction (Bowen and Shoemaker, 2003). Table 2.1 as below shows the differences between relationship marketing and traditional marketing.

\section{Table 1:- Relationship Marketing Compared with Traditional Marketing}

\begin{tabular}{|c|c|}
\hline Relationship Marketing & Traditio \\
\hline $\begin{array}{l}\text { 1. Orientation to customer } \\
\text { retention }\end{array}$ & $\begin{array}{l}\text { 1. Orientation to single } \\
\text { sales }\end{array}$ \\
\hline $\begin{array}{l}\text { 2. Continual } \\
\text { contact }\end{array}$ & $\begin{array}{ll}\text { 2. } & \begin{array}{l}\text { Episodic } \\
\text { contact }\end{array} \\
\end{array}$ \\
\hline 3. Focus on $\mathrm{cu}$ & $\begin{array}{ll}\text { 3. } & \begin{array}{l}\text { Focus on } \\
\text { features }\end{array} \\
\end{array}$ \\
\hline 4. Long term horizon & 4. Short-term horizon \\
\hline $\begin{array}{ll}\text { 5. High customer service } \\
\text { emphasis }\end{array}$ & $\begin{array}{ll}5 . & \text { little emphasis } \\
\text { customer service }\end{array}$ \\
\hline $\begin{array}{l}\text { 6. High commitment to } \\
\text { meeting }\end{array}$ & $\begin{array}{l}\text { 6. Limited commitment to } \\
\text { meeting }\end{array}$ \\
\hline 7. Customer expectations & 7. customer expectations \\
\hline $\begin{array}{l}\text { 8. Quality concerns all staff } \\
\text { members }\end{array}$ & $\begin{array}{l}\text { 8. Quality concerns only } \\
\text { production staff }\end{array}$ \\
\hline
\end{tabular}

Source: Bowen and Shoemaker, 2003

\section{Relationship Marketing Tactics}

There have been various ways for marketers to implement customer's relationship marketing tactics, which are expected to have impact on customer satisfaction and loyalty. Bansal, Taylor and James (2005) suggested that relationship marketing tactics can be executed through service quality, price perception, value offered, alternative attractiveness, and so on. Tseng (2007) discussed that tactics as direct mail, tangible rewards, interpersonal communication, preferential treatment and membership could enhance long term relationship and increase relationship satisfaction, trust and commitment. Peng and Wang (2006) also examined the application of customer relationship tactics in service quality, reputation (brand), price perception, value offers. Based on the early theories, certain customer's relationship marketing tactics which are considered of importance in service industry, such as service quality, price perception, value offers and brand image, will be focused in the following section.

\section{a) Service Quality}

Service is different from physical products. Compared with physical products, service is thought to be intangible, heterogeneous, produced and consumed simultaneously, unable to be kept in stock, etc. A widely accepted definition of service is proposed by Gronroos (1990) as a service is a process consisting of a series of more or less intangible activities that normally, but not necessarily always, take place in interactions between the customer and service employees and/or physical resources or goods and/or systems of the service provider, which are provided as solutions to customer problems (Gronroos, 2000). This definition implied that service is a process where interactions between customer and service provider most often exist. Hence, in a service context, there are almost a relationship between customer and service provider; such relationship can be used as a basis for marketing (Gronroos, 2000). In order to retain loyal customer who will bring long term profit to the firm, the key issue for service provider is to make use of this relationship in the way it manages customers by offering what the customer's needs and wants.

The quality of a service is subjectively perceived by customers during the interactions with a firm (Gronroos, 2000). Parasuraman et al. (1988) defined service quality as the consumers' judgment about a firm's overall excellence or superiority. What happens and perceived by customers in the interaction process will obviously have critical impacts on customers' evaluation of service quality (Gronroos, 2000).

Due to the peculiar attributes of service, the evaluation of service quality is more complex than evaluation of product quality. There have been various ways for measurements of service quality proposed by previous researches and literatures. The famous measurement model of service quality is SERVQUAL developed by Parasuraman et al.(1988), who measured the differences between customer expectations and perceptions cross five determinants as follows:

1. Tangibles: Appearance of physical facilities, equipment, employees and communication materials from a service company.

2. Reliability: A service company's and accurately.

3. Assurance: employees' knowledge and behavior about courtesy and ability to convey trust and confidence.

4. Responsiveness: A service company is willing to help customers and provide punctual services.

5. Empathy: A service company provides care and individualized attention to its customers, as well as having convenient operating hours.

High service quality is regarded as a key to succeed in competitive service markets. Many researchers have showed that service quality perceived by customers are directly influence customers' satisfaction, as well as their trust in the service firm (Parasuraman et al., 1988; Aydin and Ozer, 2005; Ismail et al., 2006; etc.). Customers might be satisfied when a firm provides better services than their pre purchase expectations. Customer trusts also emerge when customers perceive positive service quality from a firm, and believe the service firm would bring preferable outcomes for them. In banking industry which belongs to service industry, service quality is an important indicator to assess a service provider's performance. Offering a high quality service is considered to be a visible way to create customers trust 
and satisfaction, as well as obtaining competitive advantages and building a long term relationship with customers.

\section{b) Price Perception}

Price is the monetary cost for a customer to buy products or services. It is the critical determinant that influences customer buying decision. Customers usually select their service providers strongly relying on perceived price. How much consumers are willing to pay differs due to their different needs and wants. Thus, the price perceptions to the same service products may differ among individuals. Higher pricing perceived by consumers might negatively influence their purchase probabilities (Peng and Wang, 2006). Price perception is also thought to be related to price searching (Lichtenstein et al., 1993). Consumers are likely to be attracted by perceived high quality services at perceived competitive prices during the searching process.

Oliver (1997) suggested that consumers often judge price relating to service quality, and accordingly generate satisfaction or dissatisfaction, depending on the equity principle. If a consumer perceives price as fairness, is willing to conduct this transaction with the service provider. Based on previous studies, Cheng et. al., (2008) proposed that price perception can be measured by two dimensions: one is reasonableness of prices, which reflects the way that price is perceived by customers comparing to that of competitors. Another is value for money, which implies the relative status of the service provider in terms of price. In general, high quality services are considered to cost more than low quality equivalents (Chitty et al., 2007).

Many researchers have pointed out that price perception influences customer satisfaction \& trust (Oliver, 1997; Peng and Wang, 2006; Cheng et al., 2008; Kim et al., 2008). Customer often switches mainly due to some pricing issues, e.g. high price perceived, unfair or deceptive pricing practices (Peng and Wang, 2006). Therefore, in order to increase customer satisfaction, it is essential for service firms to actively manage their customers' price perceptions, e.g. carrying out attractive pricing, offering reasonable prices mix, lower prices without decreasing quality, etc.

\section{c) Brand Image}

Brand image was defined by Keller (1993) as the perceptions about a brand as reflected by the brand associations held in consumers' memory. It is thought as the perception or mental picture of a brand formed and held in customers' mind, through customers' response, whether rational or emotional (Dobni and Zinkhan, 1990). According to Gronroos (2000), a brand is not first built and then perceived by the customers. Instead, every step in the branding process, every brand messages, is separately perceived by customers and together sum up to a brand image, which is formed in customers' minds. Therefore, brand image is consequence of how a customer perceives the relationship with a brand over time (Ibid).

The concept of customer's relationship marketing within services displays the importance of one to one relationships between businesses and customers as well as relationships between consumers and the brands (O'Loughlin, Szmigin, and Turnbull, 2004). The development of a brand relationship with customers is based on a series of brand contacts experienced by customers (Gronroos, 2000). What customer perceives the brand image during such experience is critical issue for a service firm to realize. Furthermore, customers are likely to form brand image in mind from inexperience ways, such as word of mouth from other consumers, a company's reputation in public, marketing communication, and so on. A positive brand image make it easier for a firm to convey its brand value to consumers, also generates favorable word of mouth among people. Contrarily, negative images affect people in opposite direction; a neutral or unfamiliar image may not cause any damage, but it does not increase the effectiveness of communication and word of mouth either (Ibid, 2010). The more customers consider a brand valuable, the more sales can be expected to be achieved (Ibid, 2010).

\section{d) Value Offers}

Customers will judge the value of consumption after contrasting benefits gained from products and services with their costs (Zeithaml, 1988). Service firms provide superior value through enhanced offers can improve customer satisfaction by increasing the customer's perceived benefits and reducing the sacrifice so that customer retention is improved (Ravald and Gronroos, 1996).

It is clear that companies execute certain value adding strategies can increase customer's perceived benefits and reducing customer's perceived sacrifices, which in turn stimulate customer repurchasing activities and remain in the same service provider. In a long-term relationship, customer perceived value offered is related to both episodes and expectations (Ravald and Gronroos , 1996). When customer's expectations are satisfied, they will feel safety, credibility, and security as perceived value in this relationship, which all together increase trust and then enhance customer's satisfaction and loyalty (Ibid).

Therefore, companies should concern about customer's value from customer's point of view, and thoroughly understand customer's value chain in order to be able to reduce customer perceived sacrifice (Wilson and Jantrania, 1995).

\section{Customer Satisfaction}

Fornell (1992) defined satisfaction as an overall evaluation dependent on the total purchase and consumption experience of the target product or service performance compared with repurchase expectations over time. Oliver $(1997,1999)$ reviewed satisfaction as pleasurable fulfillment which is sensed by customers in the consumption. It means that "the consumer senses that consumption fulfills some need, desire, goal, or so forth and that this fulfillment is pleasurable" (Oliver, 1999).

In relationship marketing literatures, customer satisfaction has also been thought to be a key performance indicator for evaluating the quality of a relationship between service provider and customers. Customers' expectations regarding costs and benefits of the relationship mainly depend on past experience, and satisfying experiences increase the motivation and the likelihood that an individual stays in the relationship (Mouri, 2005). 
Figure 1: Conceptual Framework of the Study

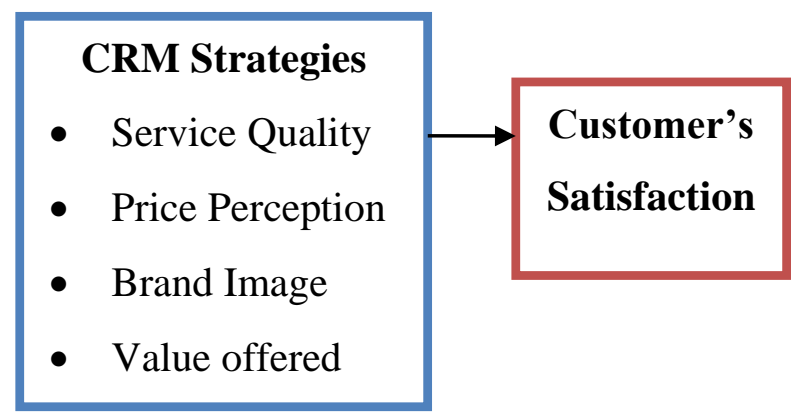

Source: Adapted from Halmstand, 2009

\section{RESEARCH METHODOLOGY}

\section{Research Design}

The type of research design employed under this study was explanatory research design. Explanatory research design was employed to investigate the effect of customer relationship market dimensions on customer satisfaction to estimate the influence of the customer relationship marketing tactics dimensions on customer satisfaction. And time wise, this study utilized crosssectional survey for data collection in the sense that all relevant data was collected at a single point in time.

\section{Research Approach}

The quantitative research involves statistical data by applying a large scale survey to collect data through close ended questionnaires or structured interviews. Hence, this research applied the quantitative research approach.

\section{Population of the Study, Sampling Technique and Sample Size}

The study population of this research constituted 26,636 saving and current account clients of Dashen Bank as of October, 2019. Dashen Bank uses an administrative operation system uniformly all across its branches throughout the country.

Taking the relative size, years of operations of the bank and cost for the study into consideration, Dashen Bank was selected by purposive sampling method and is believed to be representative samples. The sample of saving and current account clients was selected as a sample customer on the assumption that they represented Dashen Bank.

Kumar (2005) stated that a convenience sampling method is common for market research. Also Starmass (2005) stated that the advantage of adapting a convenience sampling will be cost effective and time saving. According to Star mass (2011), convenience sampling technique could deliver accurate results when the population is homogenous. Since the target populations for this study is homogenous in terms of the service it gets from the bank, the data are from convenience sample of individuals, irrespective of gender, age, occupation, level of education and personal banking details such as frequency of service usage and time periods in banking with the bank. Convenient sampling method is used in this research due to the limited budget and all the difficulty in obtaining all saving and current account customers at a time and place.
As such, the researcher used the following sample size determination formula to estimate the representative sample of the saving and current accounts in the selected banks. Taro Yamane (1973) formula was used as follows:

Where:

$$
n=\frac{N}{1+N(e)^{2}}
$$

$\mathbf{n}$ is the sample size,

$\mathbf{N}$ is the population size $=26,636$

$\mathbf{e}$ is the level of precision or sampling error $=(0.05)$

$$
\begin{aligned}
n & =\frac{26,636}{1+26,636(0.05)^{2}} \\
& =394
\end{aligned}
$$

\section{Types and Sources of Data}

In order to achieve objectives of the study, the researcher employed both primary and secondary data. Primary data were collected through self-administered questionnaires from clients of Dashen Bank at Sodo town. Secondary data were collected from an existing annual publication, reports, journals, websites, books, and research papers.

\section{Tool of Data Collections}

In this study, self-structured questionnaire was used to collect primary data as it was explanatory study, which focuses on analyzing the relationship between variables.

\section{Data Processing}

The methods of data processing in this study were both manual and computerized system. In the data processing procedure editing, coding, classification and tabulation of the collected data were used. Data processing phases have two phases namely: data clean-up and data reduction. During data clean up, the collected raw data was edited to detect anomalies, errors and omissions in responses and checking that the questions are answered accurately and uniformly or not. The process of assigning numerical or other symbols come next, which was used to reduce responses into a limited number of categories or classes. After this, the processes of classification or arranging large volume of raw data into classes or groups on the basis of common characteristics will be applied. Data having the common 
characteristics was placed together and in this way the entered data will divided into a number of groups. Finally, tabulation was used to summarize the raw data and displayed in the form of tabulation for further analysis.

\section{Methods of Data Analysis}

This is the further transformation of the processed data to look for patterns and relationship between and/or among data groups through statistical tools, namely descriptive analysis, correlation and regression analysis. The Statistical Package for Social Science (SPSS) version-20 was employed to analyze the data obtained from primary sources.

\section{Model Summary}

Multiple regression analysis was used to investigate the effect of Customer Relationship Marketing Tactics dimensions on customer's satisfaction.

\section{Regression Functions}

$Y_{i}=\mathbf{a}+\beta_{1} X_{1}+\beta_{2} X_{2}+\beta_{3} X_{3}+\beta_{4} X_{4}$

Where:

$\mathrm{Y}=$ is the dependent variable (perceived customers satisfaction), $\mathrm{a}=$ is the constant (the value of $\mathrm{y}$ when the value of all independent variables are 0 ),

$\mathrm{X}_{1}=$ Perceived service quality

$\mathrm{X}_{2}=$ Perceived fair price

$\mathrm{X}_{3}=$ Perceived value offered

$\mathrm{X}_{4}=$ Perceived brand image are the explanatory variables (or the repressor)

$\beta_{1}=$ is the intercept term it gives the mean or average effect on $\mathrm{Y}$ if all the variables excluded from the equation, although its mechanical interpretation is the average value of $Y$ when the stated independent variables are set equal to zero. $\beta_{2}, \beta_{3}$, $\beta_{4}$, and $\beta_{5}$ refer to the coefficient of their respective independent variable, which measures the change in the mean value of $\mathrm{Y}$, per unit change in their respective independent variables.

\section{DATA ANALYSIS AND INTERPRETATION: CORRELATION ANALYSIS RESULT}

Table 2: The Correlation Result of Customers Relationship Marketing Tactics and Customers Satisfaction in Dashen Bank

\begin{tabular}{|c|c|c|}
\hline & & Total Customer \\
\hline Service quality & Pearson & $0.773^{* *}$ \\
\hline & Sig.(2-tailed) & 0.000 \\
\hline & $\mathrm{N}=$ & 394 \\
\hline Price & Pearson correlation & $0.756^{* *}$ \\
\hline perception & Sig.(2-tailed) & 0.000 \\
\hline & $\mathrm{N}=$ & 394 \\
\hline Brand image & Pearson correlation & $0.279 * *$ \\
\hline & Sig.(2-tailed) & 0.000 \\
\hline & $\mathrm{N}=$ & 394 \\
\hline Value offered & Pearson correlation & $0.698 * *$ \\
\hline & Sig.(2-tailed) & 0.000 \\
\hline
\end{tabular}

This publication is licensed under Creative Commons Attribution CC BY.

http://dx.doi.org/10.29322/IJSRP.11.07.2021.p11561

\begin{tabular}{|l|l|ll|}
\hline & $\mathrm{N}=$ & 394 & \\
\hline \multirow{3}{*}{$\begin{array}{c}\text { Customer } \\
\text { Satisfaction }\end{array}$} & Pearson correlation & 1 & \\
\cline { 2 - 5 } & Sig.(2-tailed) & & \\
\cline { 2 - 4 } & $\mathrm{N}=$ & 394 & \\
\hline Correlation is & significant at the 0.01 & (2-tailed)
\end{tabular}

Source: Survey, 2020

As table 2 shows, Pearson correlation indicated that all customer relationship marketing dimensions (service quality, price perception, brand image, and value offered) are positively and significantly correlated to customers' satisfaction at 1 percent probability level of significance.

There were positive and significant relationship between all customer relationships marketing dimensions (service quality, price perception, brand image, and value offered) and customer's satisfaction. The highest and positive correlation was recorded between service quality, price perception, and value offered dimensions of customer relationships marketing tactics and customer satisfaction $(\mathrm{r}=0.773, \mathrm{p}<0.010)$, $(\mathrm{r}=0.756, \mathrm{p}<0.01)$ and $(0.698, \mathrm{p}<0.01)$ respectively. This implies that service quality and price perception dimensions of customer relationships marketing tactics have positive and significant effects on customer satisfaction. Hence, the values of the two correlations are located in between 0.6 to 0.8 , which is in the range of substantial. This implies that there is substantial association between service quality, price perception and value offered dimensions and customer satisfactions. Furthermore, as the correlation value of service quality, price perception and value offered are increased, customer satisfaction is also increased. However there was low, weak, positive and significant association exist between brand image and customer satisfaction $(r=0.279, \mathrm{p}<.01)$. This implies that brand image has low influence on the on customer satisfaction.

\section{Multiple Regression Analysis Result}

Multiple regressions are statistical techniques that can be used to analyze the association between single dependent variable and several independent variables (Anderson et.al, 2008). This is to mean that multiple regressions are used to investigate the effect of customer relationships marketing tactics dimensions on customer satisfaction. As such the sole dependent variable in this investigation was customer satisfaction and independent variables were customer relationships marketing tactics construct (service quality, price perception, brand image, and value offered).

\section{Assumptions of Multiple Regression Analysis}

Prior to running the regression model, all the explanatory variables were checked for the existence of multicollinearity effects and variance inflation factors (VIF) were used to test the assumptions of regression analysis, because the most common methods of testing the fitness of survey data to regression model analysis was multi collinearity test. Related to the VIF is the tolerance statistics, which is the reciprocal of VIF was used. As such values below 0.2 indicate that there was a serious problem (Andy F., 2014). Multicollinearity of the regression result was tested using Pearson Correlation Matrix, for each of the regression model correlation among the predicators variables were below 0.80 . 
The statistics of collinearity test results also show that all the models have a tolerance value greater than 0.2 and VIF less than
10 indicating that there was no serious multicollinearity effect in the survey data.

Table 3:- Regression result of Customer Satisfaction over MRM constructs

\begin{tabular}{|c|c|c|c|c|c|c|c|}
\hline \multirow[t]{2}{*}{ Model 1} & \multicolumn{2}{|c|}{$\begin{array}{l}\text { Unstandardized } \\
\text { coefficients }\end{array}$} & \multirow{2}{*}{\begin{tabular}{|l|}
$\begin{array}{l}\text { Standardize } \\
\text { d } \\
\text { coefficients }\end{array}$ \\
Beta
\end{tabular}} & \multirow[t]{2}{*}{$\mathbf{T}$} & \multirow[t]{2}{*}{ Sign. } & \multicolumn{2}{|c|}{$\begin{array}{l}\text { Collinearity } \\
\text { Statistics }\end{array}$} \\
\hline & B & Std. Error & & & & Tolerance & VIF \\
\hline (co.) & 0.401 & 0.048 & & 8.477 & 0.000 & - & \\
\hline SerQuality & 0.168 & 0.051 & 0.194 & 3.282 & 0.001 & 0.221 & 4.520 \\
\hline $\begin{array}{l}\text { Price } \\
\text { perception }\end{array}$ & 0.420 & 0.057 & 0.566 & 7.345 & 0.000 & 0.288 & 5.308 \\
\hline Brand image & 0.057 & 0.023 & 0.046 & 1.606 & 0.109 & 0.880 & 1.137 \\
\hline Value offered & 0.197 & 0.037 & 0.230 & 5.432 & 0.000 & 0.408 & 2.451 \\
\hline
\end{tabular}

a. Predicators:(constant, service quality, price perception, brand image, and value offered)

b. Dependent variable: customer satisfaction

*** Significant at $1 \%$ level

** Significant at $5 \%$ level

As indicated in the above table 3, customer relationship marketing dimensions were regressed against customer satisfaction. Customer relationship market dimensions (service quality, price perception, brand image, and value offered) have positive and significant effect on customer satisfaction. In the regression test shown in equation $Y_{i}=a+\beta_{1} X_{1}+\beta_{2} X_{2}+\beta_{3} X_{3}+$ $\beta_{4} \mathrm{X}_{4} \mathrm{Y}$, is dependent variable (customers satisfaction) as is $\mathrm{y}$ intercept, i.e., the value of $y$ when $X=0 \beta_{1}, \beta_{2}, \beta_{3}, \beta_{4}, \& \beta_{5}$ is the regression coefficient of service quality, price perception, brand image, and value offered respectively, which indicates the amount of change in $Y_{i}$ for a given unit change in $X_{i}$ and finally $X$ is the value of independent variable. The result is as under:

$\mathrm{Y}=0.401+0.168 \mathrm{x}_{1}+0.420 \mathrm{x}_{2}+0.057 \mathrm{x}_{3}+0.197 \mathrm{x}_{4}$

Where $\mathrm{Y}=$ Customer Satisfaction

$\mathrm{x}_{1}=$ Service quality

$\mathrm{x}_{2}=$ Price perception

$\mathrm{x}_{3}=$ Brand image

$\mathrm{x}_{4}=$ Value offered

Therefore from the above table, estimated $\mathrm{Y}=$ $0.401+0.168 \mathrm{x}_{1}+0.420 \mathrm{x}_{2}+0.057 \mathrm{x}_{3}+0.197 \mathrm{x}_{4}$. Hence, from the regression result of unstandardized beta coefficients of service quality, price perception, brand image, and value offered were $0.168,0.420,0.057$ and 0.197 respectively. This implies that service quality, price perception, brand image, and value offered have as a significant contribution in influencing clients' satisfaction. In addition to this as service quality, price perception, brand image, and value offered increased by $0.168,0.420,0.057$ and 0.197 respectively customers' satisfaction is increased by one unit.

Furthermore, price perception score is the largest positive and significant value among the four customer relationship market tactics dimensions. This implies that as the value offered is increased by 0.420 unit customers satisfaction is increased by one unit. However, brand image is the least positive and in significant value among the four customer relationship market tactics dimensions. This implies that even though brand image is one of the dimensions of customer relationship market tactics it does not have significant contributions in clients' satisfactions. Whether brand image is increased or decreased it does not have any influence on clients' satisfactions.

Table 4: Analysis of Customers Relationship Market Tactics and Customer Satisfaction (ANOVA)

\begin{tabular}{|l|l|l|l|l|l|l|}
\hline \multicolumn{2}{|l|}{ Model } & $\begin{array}{l}\text { Sum of } \\
\text { Squares }\end{array}$ & Df & $\begin{array}{l}\text { Mean } \\
\text { Square }\end{array}$ & F & Sig. \\
\hline 1 & Regression & 38.586 & 4 & 9.646 & 247.904 & $0.000 \mathrm{~b}$ \\
\hline & Residual & 14.748 & 379 & 0.039 & & \\
\hline & Total & 53.333 & 383 & & & \\
\hline
\end{tabular}

a. Predicators:(constant, service quality, price perception, brand image, and value offered)

b. Dependent variable: customer satisfaction $\quad F=252.344$ Source: Survey, 2020

From the above regression result table, the overall customer relationship market tactics dimensions have significant effect on customer satisfaction $(\mathrm{P}<0.000)$. This implies that the overall variations in customer satisfaction were explained by the four dimensions of customer relationship market tactics. In addition to this, the proposed model is adequate as the F-static $=247.904$, were significant at one percent level $(\mathrm{p}<0.01)$. This represents that the model was reasonable fit and there was statistically significant association between customer relationship market tactics dimensions (service quality, price perception and value offered) and customer satisfaction. This implies that multiple regressions were reasonable to measure the effects of customer relationship market tactics on customer satisfaction.

Table 5: Model Summary for Regression Analysis

\begin{tabular}{|l|l|l|l|l|}
\hline Model & $\mathbf{R}$ & $\begin{array}{l}\mathbf{R} \\
\text { Sauare }\end{array}$ & $\begin{array}{l}\text { Adjusted } \mathbf{R} \\
\text { Sauare }\end{array}$ & $\begin{array}{l}\text { Std. Error of the } \\
\text { Fstimate }\end{array}$ \\
\hline 1 & $0.851^{\mathrm{a}}$ & 0.723 & 0.721 & 0.19720 \\
\hline
\end{tabular}

a. Predicators:(constant, service quality, price perception, brand image, and value offered) 
b. Dependent variable: customer satisfaction Source: Survey, 2020

$R^{2}=.723 \quad$ Adjusted $R^{2}=0.721$

The regression results show that service quality, price perception, brand image, and value offered altogether significantly influence customer satisfaction. From the above table of the regression model one, the coefficient of determination adjusted $\left(\mathrm{R}^{2}\right)$ was 0.721 demonstrated that 72.1 percent of total customer satisfaction could be explained by the four dimensions of customer relationship market tactics (service quality, price perception, brand image, and value offered) while the rest $(27.9 \%)$ of the variations in client satisfaction could be accounted for the other factors, which could be beyond the scope of the study.

\section{HYPOTHESIS TESTING}

Hypothesis testing was based on the standardized coefficient beta with 95\% confidence level and p-value to test whether hypothesis is accepted or rejected in three branches.

Ho1: Perceived service quality has no effect on customer satisfaction.

This prediction was not supported by the data because according to the SPSS version 20 result that service quality contributes to positive and significant effect on customer satisfaction $\left(\boldsymbol{\beta}_{\mathbf{1}}=\mathbf{0 . 1 6 8}, \mathbf{p}<\mathbf{0 . 0 1}\right)$. Therefore, the alternate hypothesis can be accepted; that is, service quality dimension of customer relationship market tactics has positive and significant effect on customer satisfaction in Dashen Bank.

H02: Perceived fair price has no effect on customer satisfaction.

The hypothesis was not supported by the survey results. The value of price perception contribution to the customer satisfaction is $\left(\boldsymbol{\beta}_{2}=\mathbf{0 . 4 2 0}, \mathbf{p}<\mathbf{0 . 0 1}\right)$. So the constructed hypothesis can be rejected. Finally it can be concluded that there is a positive and significant relationship between price perception and customer satisfaction. Therefore the null hypothesis is rejected and the alternative hypothesis was rejected.

H03: Perceived positive brand image has no effect on customer satisfaction.

The hypothesis was not supported by the data because the contribution to the customer satisfaction has taken a positive and insignificant value $\left(\boldsymbol{\beta}_{\mathbf{3}}=\mathbf{0 . 0 5 7}, \mathbf{p}>\mathbf{0 . 0 5}\right)$. The developed hypothesis was not supported by the findings. Finally, the researcher concludes that there is a positive and in significant relationship between brand image and customer satisfaction (the null hypothesis was accepted).

H04: Perceived value offered has no effect on customer satisfaction.

The hypothesis was supported by the data because the value offered contributes to the customer satisfaction is $\left(\boldsymbol{\beta}_{\mathbf{4}}=\mathbf{0 . 1 9 7}, \mathbf{p}<\right.$ 0.01). Therefore, the postulated hypothesis can be accepted according to the data. Therefore, it can be concluded that there is a positive and significant relationship between value offered and customer satisfaction. Therefore the null hypothesis is rejected and the alternative hypothesis was rejected.

\section{CONCLUSIONS}

The main aim of this study is to assess the effect of customer relationship market tactics on customer satisfaction in the bank. Hence, the results revealed that the three dimensions of customer relationship market tactics (service quality, price perception and value offered) have positive and significant effect on client satisfaction. But one variable, brand image has positive but insignificant effect on customer satisfaction. The finding of this study also indicated that price perception was the most important factors to have positive and significant effect on client satisfaction in the bank followed by value offered and service quality. This implies that price perception is the most important factors affecting customer satisfaction. The dimensions of market relationship management dimensions explain the variations in saving account and account customer satisfaction by 72.1 percent in the bank.

\section{RECOMMENDATIONS}

Based on the findings and conclusions reached, the researcher forwarded the following recommendations focusing on issues, which may have managerial implications.

- As the study results showed, the bank can improve customer's satisfaction by improving customer perception towards service quality, price perception, brand image, and value offered dimensions. Managerial efforts better aim at boosting customer satisfaction by improving these four customers relationship market dimensions. Therefore, to make the service appealing to customers, the bank should highly focus on improving their customer relationship market tactics package. This market relationship management package is also communicated to target customers.

- In order to ensure customers satisfaction according to the needs and wants of clients, the bank management better train their employees on customer relationship marketing tactics, focusing on improving their skills and knowledge on how to understand customers, provide accurate and prompt service.

- Although brand image dimension of customer relationship market tactics are considered as one of the most important factors influencing customer satisfaction, clients of the bank were found less satisfied with this dimension of customer relationship market tactics. One way of addressing this issue can be training employees in building high reputation of the bank, promoting confidence in customer, having a good feeling about the employee social responsibility and delivering a good brand image to its customers.

- $\quad$ Furthermore, the bank should develop brand relationship with customers based on series of brand contacts. It should develop positive brand image in an experienced ways (positive word of mouth from customers from bank reputations in public and marketing communications). Positive image make it easier for a firm to convey its brand value to customers.

- Finally, the finding of the study also indicated that customer of the bank were satisfied with customer 
relationship market tactics of the bank. The finding of the study also indicates that clients of the bank were satisfied with the majority of customer relationship market tactics. However, this does not mean it lasts forever. Therefore, there is a need for management bodies of the bank to evaluate continuously to bring a continuous improvement in customers satisfaction.

\section{REFERENCES}

[1] Andaleeb, S. S. (1996). An Experimental Investigation of Satisfaction and Commitment in Marketing Channels: The Role of Trust and Dependence. Journal of Retailing, 72. (1), 77-93.

[2] Anderson, E., \& Weitz, B. (1989). Determinants of continuity in conventional industrial channel dyads. Marketing Science, 8 (4), 310-323.

[3] Anderson, J. C., \& Narus, J. A. (1990). A model of distributor firm and manufacturer firm working relationships. Journal of Marketing, 54 (1), 42 58 .

[4] Aydin, S., \& Özer, G. (2005). The analysis of antecedents of customer loyalty in the Turkish mobile telecommunication Market. European Journal of Marketing, 39 (7/8), 910-925.

[5] Bansal, H. S., Taylor, S. F., \& St. James, Y. (2005). Migrating to New Service Providers: Toward a Unifying Framework of Consumers Switching Behaviors. Journal of the Academy of Marketing Science, 33 (1), 96-115.

[6] Berry, L. L. (1995). Relationship marketing of service: Growing Interest, emerging perspective. Journal of the Academy of Marketing Science, 23 (4), 236-245.

[7] Bitner, M. J., Booms, B. H., \& Tetreault, M. (1990). The service encounter: diagnosing favorable and unfavorable incidents. Journal of Marketing, 54 (1), 71-84.

[8] Boone, \& Kurtz. (2005). Contemporary Marketing (1st ed.). South Western, Thomson Corporation.

[9] Bowen, J. T., \& Shoemaker, S. (2003). Loyalty: A Strategic Commitment, Cornell Hotel and Restaurant Administration Quarterly, Oct-Dec 2003. 44 (5/6), 31-46.

[10] Cheng, T. C., Lai, L. C., \& Yeung, A. C. (2008). The Driving Forces of Customer Loyalty: A Study of Internet Service Providers in Hong Kong. International Journal of E-Business Research, 4 (4), 26-42.

[11] Chitty, B., Ward, S., \& Chua, C. (2007). An application of the ECSI model as a predictor of satisfaction and loyalty for backpacker hostels. Marketing Intelligence and Planning, 25 (6), 563-580.

[12] Chu, K.-M. (2009). The Construction Model of Customer Trust, Perceived Value and Customer Loyalty. The Journal of American Academy of Business, Cambridge, 14 (2), 98-103.

[13] Creswell, W. (2002).Research Design: Qualitative, Quantitative and Mixed Methods approach (2nd ed.). New Delhi, India: Sage publication, Inc.

[14] Crosby, L. A., Evans, K. R., \& Cowles, D. (1990). Relationship Quality in Services Selling: An Interpersonal Influence Perspective. Journal of Marketing, 54 (3), 68-81.

[15] Drucker, P. F. (1954). The Practice of Management. New York: Harper \& Row.

[16] Duncan C. \&Dennis H.(2004).A Practical ResourceforStudents in theSocialSciencesTheSAGE Dictionaryof StatisticsLondon, Sage Publications.

[17] Egan, J. (2001).Relationship Marketing: Exploring Relational Strategies in Marketing. Pearson Education Limited.

[18] Ehigie, B. (2006). Correlate of customer loyalty to their banks: a case study in Nigeria. International Journal of bank marketing, 24 (7), 494-505.

[19] Fornell, C. (1992). A national customer satisfaction barometer: The Swedish experience. Journal of Marketing, 56 (1), 6-21.

[20] Geyskens, I., Steenkamp, J.-B. E., \& Kumar, N. (1998). Generalizations about trust in marketing channel relationships using meta-analysis. International Journal of Research in Marketing, 15 (July), 223-248.

[21] Gilbert, D. F. (1996). Airlines, In Relationship Marketing: Theory and Practice (Buttle ed.). London: Paul Chapman Inc.
[22] Grönroos, C. (2000).Service Management and Marketing: A Customer Relationship Management Approach (2nd ed.). John Wiley \& Sons, Ltd.

[23] Grönroos, C. (2004). The Relationship Marketing Process: Communication, Interaction, Dialogue, Value. The Journal of Business \& Industrial Marketing, 19 (2), 99-113.

[24] Hayes, B. E. (2008). The True Test of Loyalty. Quality Progress, 41 (6), 20 26.

[25] Hougaard, S., \& Bjerre, M. (2002). Strategic Relationship Marketing. Sam funds litterateur Press.

[26] Ismail, I., Haron, H., Ibrahim, D. N., \& Isa, S. M. (2006). Service quality, client satisfaction and loyalty towards audit firms: perceptions of Malaysian public listed companies. Managerial Auditing Journal, 21 (7), 738-756.

[27] Jamal, A., \& Kemal, N. (2002). Customers satisfaction and Retail Banking: an assessment of some of the key antecedents of customers satisfaction in retail banking. International Journal of Bank marketing, 20 (4), 146-160.

[28] Keaveney, S. M. (1995). Customer switching behavior in service industries: an exploratory study. Journal of Marketing, 59 (2), 71-82.

[29] Keiningham, T. L., Aksoy, L., Cooil, B., \& Andreassen, T. W. (2008). Linking Customer Loyalty to Growth. MITS loan Management Review, 49 (4), 50-57.

[30] Keller, K. (1993). Conceptualizing, measuring, managing customer-based brand equity. Journal of Marketing, 57 (1), 1-22.

[31] Kim, C. S., Zhao, W. H., \& Yang, K. H. (2008). An Empirical Study on the Integrated Framework of e-CRM in Online Shopping: Evaluating the Relationships among Perceived Value, Satisfaction, and Trust Based on Customers' Perspectives. Journal of Electronic Commerce in Organizations, $6(3), 1-19$.

[32] Kotler, P., \& Gary, A. (2010). Principles of Marketing (13th ed.). Pearson Education, Inc.

[33] Kotler, P., \& Kevin, L. K. (2007). Marketing Management. Dorling Kindersley (India) Pvt. Ltd.

[34] Lages, C., Lages, C. R., \& Lages, L. F. (2005). The RELQUAL scale: a measure of relationship quality in export market ventures. Journal of Business Research, 58, 1040-1048.

[35] Leong, Y. P., \& Qing, W. (2006). Impact of relationship marketing tactics (RMTs) on switchers and stairs in a competitive service industry. Journal of Marketing Management, 22, 25-29.

[36] Li, L. (2008). Study of the relationship between customer satisfaction and loyalty in telecom enterprise. 2008 IEEE International Conference on Service Operations and Logistics, and Informatics, 1, 896-901.

[37] Li, Y.-C., \& Ho, Y.-C. (2008). Discuss the Impact of Customer Interaction on Customer Relationship in Medical Service. The Business Review, Cambridge, 11 (1), 152-158.

[38] Liang, C.-J., \& Wang, W.-h. (2008). Do Loyal and More Involved Customers Reciprocate Retailer's Relationship Efforts? Journal of Services Research, 8 (1), 63-90.

[39] Lim, P., \& Tang, N. (2000). A study of patients' expectations and satisfaction in Singapore hospitals. International journal of Health care Quality Assurance, 13 (7), 290-299.

[40] Liou, J. J. (2009). A novel decision rules approach for customer relationship management of the airline market. Expert Systems with Applications, 36 (3), 4374-4381.

[41] Liu, Y., Li, Y., Tao, L., \& Wang, Y. (2008). Relationship stability, trust and relational risk in marketing channels: Evidence from China. Industrial Marketing Management, 37, 432-446.

[42] Mayer, R. C., Davis, J. H., \& Schoorman, F. D. (1995). An integrative model of organizational trust. Academy of Management Review, 20 (3), 709-734.

[43] Melaku, Y. (2013). Influence of quality services on customers' satisfaction and loyalty: the case of commercial bank of Wolaita Sodo

[44] Morgan, R. M., \& Hunt, S. (1994). The Commitment-Trust Theory of Relationship Marketing. Journal of Marketing, 58 (July), 20-38.

[45] Mouri, N. (2005). A Consumer-based Assessment of Alliance Performance: An Examination of Consumer Value, Satisfaction and Post-purchase behavior. University of Central Florida , 156.

[46] Ndubisi, N. O. (2004). Cross Cultural Management. Understanding the salience of cultural dimensions on relationship marketing, its underpinnings and aftermaths. 11 (3). 
[47] Ndubisi, N. O., \& Wah, C. K. (2005). Factorial and discriminant analysis of the underpinnings of relationship marketing and customer satisfaction. International Journal of Bank Marketing, 23 (7), 542-557.

[48] O'Loughlin, D., Szmigin, I., \& Turnbull, P. (2004). Branding and relationships: customer and supplier perspectives. Journal of Financial Services Marketing, 8 (3), 218-230.

[49] Oliver, R. L. (1999). When consumer loyalty? Journal of Marketing, 63, 3344.

[50] Oliver, R. (1989). Processing of satisfaction Responses in Consumption: A suggested Frame Work and Research Propositions. Journal of Customer satisfaction, Dissatisfaction and Complaining Behavior, 2, 1-16.

[51] Parasuraman, A., Zeithamal, V. A., \& Berry, L. L. (1998). SERVQUAL: A multiple-item scale for measuring consumer perceptions of service quality. Journal of Retailing, 64, 12-40.

[52] Patterson, P. G., \& Smith, T. (2003). A cross-cultural study of switching barriers and propensity to stay with service providers. Journal of Retailing, 79 (2), 107-120.

[53] Peng, L. Y., \& Wang, Q. (2006). Impact of Relationship Marketing Tactics (RMTs) on Switchers and Stairs in a Competitive Service Industry. Journal of Marketing Management, 22, 25-59.

[54] Peppers, D., \& Rogers, M. (2004).Managing Customer Relationships: A strategic Framework. Hoken, New Jersey: John Wiley \& Sons, Inc.

[55] Ravald, A., \& Gronroos, C. (1996). The value concept and relationship marketing. European Journal of Marketing, 30 (2), 19-30.

[56] Reichheld, F. (1996). The Loyalty Effect. Cambridge: MA: Harvard Business School.
[57] Rick, F., \& Kelly, H. (2007). Choosing the right tools for your relationship banking. Journal of Consumer Marketing, 24 (2), 110-117.

[58] Russell, L., \& Robert, M. M. (2009). Customer advocacy and the impact of B2B loyalty programs. Journal of Business \& Industrial Marketing, 24 (1), 3-13.

[59] Saunders, M., Lewis, P., \& Thomhil, A. (2000).Research Methods for Business Students (2nd ed.). London: Pearson Education Limited.

[60] Taro, Y. (1973).Statistics, An Introductory Analysis (3rd ed.). New York: Harper and Row.

[61] Tsoukatos, E., \& Rand, G. (2006). Path analysis of perceived service quality, satisfaction and loyalty in Greek insurance. Managing Service Quality, 16 (5), 501-519.

[62] Yi, Y. (1990). A critical review of consumer satisfaction: Review of marketing. American Marketing association, Chicago, IL.

[63] Zeithaml, V.Parasuraman, \& A.Berry, L. (1990). Customer service, service industry Quality, Control Mathematical Models.

\section{AUTHORS}

First Author - Biruktait Girma Giday, Lecturer, Wolaita Sodo University, mbiruktaitgirma@gmail.com

Second Author - Million Nane Elcho (PhD), Assistant

Professor, Department of Management, Wolaita Sodo University, bmillionnane@gmail.com 